\title{
MACROECONOMIC DETERMINANTS OF STOCK PRICE VARIATIONS: AN ECONOMIC ANALYSIS OF KSE-100 INDEX
}

\author{
ALTAF HUSSAIN \\ Lecturer, Department of Economics, \\ The Islamia University of Bahawalpur, Pakistan \\ Bahawalnagar Campus. \\ Email: altafhussain@iub.edu.pk \\ MUSRAT RAFIQUE \\ M. Sc. Scholar of Economics, \\ The Islamia University of Bahawalpur, Pakistan \\ Bahawalnagar Campus. \\ AMBAR KHALIL \\ Research Scholar of Economics, \\ The Islamia University of Bahawalpur, Pakistan, \\ Bahawalnagar Campus. \\ Email: amberkhalil70@gmail.com \\ MARYAM NAWAZ \\ M. Phil. Scholar of Economics, \\ National College of Business Administration \& Economics, Lahore. \\ Multan Campus \\ Email: maryamnawaz563@gmail.com
}

\begin{abstract}
The main objective of this study is to assess the macroeconomic determinants of stock price variability in Pakistan. The quarterly data on macroeconomic variables (Gross Domestic Product, Foreign Direct Investment, Interest Rates, Exports, Money Supply and Unemployment Rate) and KSE-100 Index as proxy of stock price variation for the period of 1992:01 to 2012:04 is taken for the empirical investigation. Johansen co-integration test and VECM is used for this purpose. The analysis of this study specifies that the foreign direct investment, interest rates, export and unemployment rate have significant and negative impact on KSE-100 index, while money supply has found to be a significant and positive determinant of stock prices. On the other hand gross domestic product have a positive but insignificant impact on stock prices in Pakistan.
\end{abstract}

Keywords: Macroeconomics, Financial Markets, Stock Exchanges, Index, Cointegration, VECM, Time Series, Stationary Series

JEL Classification Codes: B22, C22, C43, C51, E44, 016 


\section{INTRODUCTION}

Stock markets play a vital role in development and growth of any global economy. It is hard to imagine a prosperous economy in the absence of stock markets. Role of these markets is important in the way that they mobilize the domestic resources of the economy and channel them to productive investment (Comincioli, 1995). The performance of stock market is gauged through movement in its index which is influenced by many factors such as companies' specific factors, domestic (macroeconomic, social and political) and international factors.

The well-organized stock markets mobilize the savings and activate the investment projects, which lead to economic activities in a country. The key function of stock market is to act as mediator between savers and borrowers. It mobilizes savings from a large pool of small savers and channelizes these funds into fruitful investments. The preferences of lenders and borrowers are harmonized through stock market operations. The stock market also supports reallocation of funds among corporations and sectors. It also provides liquidity for domestic credit expansion and consequently, economic growth. The leading stock markets of the world observed negative growth ranging from 2.9 percent (China) to 50.7 percent (Pakistan) during the financial year 2008-09.

\section{A. FINANCIAL MARKET}

A financial marketplace is a market in which consumers and suppliers contribute in the occupation of properties such as equities, promises, exchanges and products. Commercial markets are logically defined by having clear pricing, basic guidelines on trading, costs and dues and market services defining the values of securities that trade. Particular financial markets only allow contributors that meet definite criteria, which can be created on features like the volume of money believed, the stockholder's geographic location, information of the marketplaces or the occupation of the contributor.

\section{B. CAPITAL MARKET}

Markets for purchasing and selling parity and obligation of the instruments. Capital markets network funds and assets among sellers of capital such as selling shareholders and formal shareholders and consumers of investment like industries, administration and persons. Capital markets exist energetic to the effective of an economy, since capital is a dangerous factor for producing economic return. Capital markets include primary markets, 
where a new stock and bond issues are traded to shareholders, and secondary markets, which trade prevailing securities.

\section{STOCK MARKET}

The market in which shares of publicly held corporations are issued and traded either through conversations or over-the-counter markets. The performance of a nation's stock market is believed to be a reflection of that country's economy. Since the previous few eras the reputation of stock market round the world unlocked different pathway of the investigation into the financial progress and growth of stock market growth. Numerous researchers in this area showed that share prices are determined on the base of macroeconomic influences such as industrial production, interest rate, consumer price index, inflation rate, exchange rate money supply etc. Stock analysts usually believe that economic factors measure an enormous effect on the stock market prices. The outcomes of such studies not only changed the behavior of stock holders' judgment of stock but also encouraged various researchers to explore the association among macroeconomic variables and stock prices.

Therefore, foremost objective of the present study is to assess the contributing macroeconomic factors of variations in Karachi Stock Exchange (KSE-100) index. First section of this article introduces the main topic and followed by literature review in second section. Data and methodological discussion appears in $3^{\text {rd }}$ section. In $4^{\text {th }}$ part, empirical results are discussed. Whereas this paper is conclude in $5^{\text {th }}$ section and references are given in $6^{\text {th }}$ and last section of the paper.

\section{II.LITERATURE REVIEW}

Nishat \& Shaheen (2004) observed the association amongst the set of macroeconomic variables and Karachi stock exchange index by using quarterly time series data ranging from 1973/1 to 2004/4. The set of variables involved in analysis were index of industrial production, money supply, inflation, interest rate and consumer price index. To identify long run relationship vector error correction model (VECM) was employed. The outcomes of the study indicated that these five variables were co integrated and two longrun relationships were established between the variables. It was establish that inflation was negative factor of stock market. But on the other hand, a positive and strong influence of industrial production index on stock prices was found. 
Maysami, Howe, \& Hamzah (2004) examined the long-term stability affairs among nominated macroeconomic variables and the Singapore stock market index (STI) as well as other Singapore Exchange Market's sector indices i.e. finance index, property index and hotel index. The researchers used monthly data from January 1989 to December 2001 and used Johanson Co-integration and Engel Granger for analysis. Finally it was concluded that the Singapore's stock market and the property index took significant short run as well as long run association with macroeconomic variables such as interest rate, exchange rate, industrial production, inflation and money supply.

Menike (2006) investigated the effects of macroeconomic variables including money supply, exchange rate, interest rate and inflation on stock prices in evolving Sri Lankan stock market by using monthly data for the period from September 1991 to December 2002. The multiple regression used to find out the influence of macroeconomic variables on stock prices. The fitted regression model revealed a strong association among macroeconomic variables and stock prices. The empirical analysis specified that twenty seven stocks out of thirty four took higher explanatory influence of more than $50 \%$ in the monthly stock prices for the period 1991 to 2002 , the period which provided the strongest indication of macroeconomic variables as the stimulus of changing stock prices.

Adam \& Tweneboah (2008) examined the role of macroeconomic variables in Ghana's stock market performance through the period of January 1991 to December 2006. Databank Stock Index (DSI) was used as dependent variable but interest rate, inflation, net foreign direct investment and exchange rate were used as independent variables. For empirical analysis purposes, vector error correction (VECM) was estimated. Moreover, the long run association among share prices and set of macroeconomic variables using Johansen's multivariate co-integration tests. Short run dynamics were found using instinct response function and estimate error variance decomposition investigation. The FEVD test consequences specified inflation explain minor portion of the variation of the share prices compared to interest rate, net FDI inflow and exchange rate.

Hasan \& Nasir (2008) examined the influence of inflation, industrial production, short term interest rate, exchange rates, oil prices, foreign portfolio investment, and money supply on equity prices in Pakistan for the period 1998/6 to 2008/6 by using bounds testing method anticipated by Pearson et al (2001). Results of ARDL long run measurements uncovered that industrial production, oil prices and inflation are not statistically significant in 
defining equity prices in long run although interest rates, exchange rates and money supply had significant long run influence on equity prices.

Ozbay (2009) investigated Turkish stock prices and its relationship with macroeconomic variables such as inflation, interest rate, money supply, industrial production, exchange rate over the period of 1998 to 2008. Granger causality was employed to discovering such relationship. Permitting to the discoveries of the learning, stock prices were positively related to foreign investor contacts but negatively to interest rate. Conversely, the association among stock proceeds and other macroeconomic variables such as money supply, inflation, industrial production and exchange rate were statistically insignificant.

Sohail \& Hussain (2009) established that there were long-run and short-run correlation among macroeconomic variables and stock earnings in Lahore stock exchange for the period of December 2002 to June 2008. Co integration test was used to see this relationship empirically. The study recognized that inflation adversely affected the stock returns although there was a positive effect of industrial production, money supply and real effective exchange rate on stock prices.

Khalid, Altaf, Mehmood \& Hussain (2010) examined the long run relationship of macroeconomic variables on Karachi Stock Exchange (KSE) return. The monthly data of exchange rate, Treasury bill, inflation and Stock return was taken for the period of January 2000 to December 2010. The results of descriptive measurements discovered that KSE was providing highest return. The outcomes of co-integration presented no long run connection occurs among variables and KSE share prices. All consequences presented that macroeconomic variables and share prices had no long run association but influence on stock returns was only due to lagged stock prices.

Ali, Rehman, Yilmaz, Khan, \& Afzal (2010) used Johansen's co-integration and Granger's Causality Test on time series data from the period of June 1990 to December 2008 to observe the association among several macroeconomic variables and stock market prices in Pakistan. They used balances of trade, exchange rate, inflation rate and industrial production index as macroeconomic variables. The result of the study indicated that there was no causal association among macroeconomic variables and stock exchange prices, only co-integration was established among industrial production index and stock 
exchange prices. Lastly conclusion suggested that variability of macroeconomic variables cannot forecast stock exchange prices hence stock market prices had not revealed by the macroeconomic circumstance of Pakistan.

Pal \& Mittal (2011) examined the long-run association among the Indian capital markets' performance and important macroeconomic variables such as inflation rate, exchange rates, interest rates and gross domestic savings (GDS) of Indian economy. Quarterly time series data covering the period from January 1995 to December 2008 had been used. The unit root test, the co-integration test and error correction model (ECM) had been adopted to analyze the long run and short run econometric dynamics. The outcomes of the study found that there was co-integration among macroeconomic variables and Indian stock market performance which was an evidence of a long-run association among dependent and independent variables. The ECM demonstrated that the inflation had a significant influence on stock index (BSE).

Naik \& Padhi (2012) studied the association among the Indian stock market index and macroeconomic variables, i.e., index of industrial production, money supply, wholesale price index, treasury bills rate and exchange rate over the period 1994/4 to 2011/6. . Findings of co-integration and error correction mechanism showed that the stock prices definitely correlated to the industrial production and money supply but adversely correlated to inflation. The exchange rate and the short term interest rate were remained insignificant in determining stock prices.

Ozlen \& Ergun (2012) examined the impact of some selected macroeconomic variables including inflation rate, interest rate, current account deficit, exchange rate and unemployment rate on stock earnings of 45 corporations from 11 different sectors. Autoregressive distributed lag technique was applied on the monthly time series data on macroeconomic variables and stock prices of 45 Turkish companies from 11 different sectors covering from the period February, 2005 to May, 2012. The general conclusion was made that exchange rate and interest rate were the most significant influencer of the Turkish corporations' stock price variations. Stock earnings of the corporations in any industry were very sensitive to the variations in exchange rate and interest rate.

Ray (2012) explored the effect of different macroeconomic variables on the stock prices in India expending yearly data from 1990-91 to 2010-11. A multiple regression model had designed to test the effect of macroeconomic variables on the stock prices and granger 
causality test was employed to observe whether there exist any fundamental relationship among stock prices and macro-economic variables. Estimated results of multivariate Granger causality designated that there was no causal relationship among stock prices and macroeconomic variables. The multiple regression consequences of the study described that oil price and gold price had a significant negative effect on stock price, while balance of trade, interest rate, foreign exchange reserve, gross domestic product, industrial production index and money supply positively encouraged Indian stock prices.

Saeed (2012) examined the influence of macroeconomic variables on stock return in Pakistan by applying multifactor model within an APT frame work. This study used five macroeconomic variables Money Supply, Exchange Rate, Industrial Production, Short Term Interest Rate and Oil prices. Nine sectors were selected for the study on the basis of data availability on the Karachi Stock Exchange 100 index. The closing prices of each firm of each sector were obtained for the period of ten years ranging from June 2000 to June 2010. Outcomes demonstrated that the influence of macroeconomic influences on the earnings of sectors was significant except on jute sector. Oil prices had only shown a positive and significant impact on oil and gas sector. Therefore, oil prices were positively related to equity prices.

Hussain, Aamir, Rasool, Fayyaz, \& Mumtaz (2012) explored the effect of different macroeconomic variables on the stock prices in India by using annual data from 1990-91 to 2010-11. A multiple regression model was designed to assess the effects of macroeconomic variables on the stock prices and granger causality assessment was applied to observe whether any causal relationship among stock prices and macroeconomic variables exist or not. Approximations of multivariate Granger causality specify that there was no causal relationship among stock prices and macroeconomic variables. The outcomes multiple regression of the study specified that oil price and gold price had a significant negative influence on stock price, while balance of trade, gross domestic product, industrial production index, interest rate, foreign exchange reserve and money supply positively affect Indian stock prices.

Yogaswari, Nugroho, \& Astuti (2012) explored the impact of macroeconomic variables on the stock price movement in Indonesian Stock Exchange. Three variables of macroeconomics i.e. inflation, interest rate, and exchange rate were used as independent variables. Jakarta Composite Index $(\mathrm{JCl})$, agriculture sector, and basic industry sector 
stock price were used as dependent variable. The monthly time series data were collected from Bank Indonesia and Yahoo Finance over the period of January 2007 to December 2011. Multiple regression technique was applied to build a quantifiable model presenting the association among macroeconomics and stock price. The empirical consequences of the study spelled out a significant association between macroeconomic variables and stock price of $\mathrm{JCl}$, agriculture sector, and basic industry sector. The variation in inflation influenced the stock prices positively but on the other hand variation in interest rate and inflation translated negatively in the stock price of $\mathrm{JCl}$, agriculture sector, and basic industry sector.

Rafique, Amara, Naseem, \& Sultana (2013) identified the impact of four macroeconomic variables i.e. GDP per capita, gross domestic savings, Inflation and Discount rate on KSE 100 index of Pakistan. Time series data for 20 years from 1991 to 2010 was collected. SPSS was used to test the multiple regression model. The study concluded that CPI and Discount rate had negative significant relationship with KSE 100 index while the per capita income and gross domestic savings to GDP per cent age had positive significant relationship.

Bellalah, Levyne, \& Masood (2013) ascertained the association among the stock exchange prices and macroeconomic variables i.e. term of trade, oil prices, interest rate, money supply (M3) and industrial production index focusing particularly on current international economic crises. The monthly data on the all selected variables for the period of January 2005 to May 2010 for USA, Japan and China. The consequences showed that in USA and China, in long run as well as short run interest rate, industrial production index and Money supply (M3) were positively associated to the stock exchange prices. The results for Japan showed that interest rate was positively and extremely significantly in long run but in short run, at first lag it had positive but at second lag it had negative relationship with stock exchange prices.

\section{DATA AND METHODOLOGY}

As identified by the literature review, up to now different methodologies have been used to assess the stock price variations in different countries. After reviewing the literature on stock price variation especially in terms of stock indices of different stock exchanges of the world and macroeconomic determinants of these variations, six most important determinants are identified. Quarterly time series data for the period of 1992:01 to 2012:04 
on KSE-100 Index (KSE-100) as dependent variable and independent variables i.e. Gross Domestic Product (GDP), Foreign Direct Investment (FDI), Interest Rate (IR), Export (X), Money Supply (MS) and Unemployment Rate (UR) is taken from World Development Indicators (WDI) published by World bank, International Financial Statistics (IFS) by International Monetary Fund (IMF) and Hand Book of Statistics published by State Bank of Pakistan (SBP).

\section{A. VARIABLE DESCRIPTION}

For our assessment of KSE-100 Index and its determinants, following variable has been identified. Description and their expected relationship with dependent variable are discussed below.

\section{KSE-100 INDEX}

Karachi Stock Index (KSE) 100 Index is used as a proxy of overall stock prices in the leading and major stock exchange of Pakistan.

\section{GROSS DOMESTIC PRODUCT}

The total income earned domestically, including the income produced by foreign owned factors of production; the total spending on domestically produced goods and services. The higher the growth rate of GDP, other things being equal, the more encouraging it is for the stock market (Chandra 2004). Equity prices may rise due to the higher profits from a strong business climate.

\section{FOREIGN DIRECT INVESTMENT}

Foreign Direct Investment (FDI) is an investment made by a person or organization in a particular foreign country. FDI tends to be higher in nations that are riskier, economically undersized, and institutionally weak. Under this view, FDI is a substitute for stock market growth. FDI takes place to speechless the problems of financing over capital markets, given that stockholders privileges are not secure. In view of this, FDI would be negatively related with the stock price of stock markets.

\section{INTEREST RATES}

Interest rate is the price of borrowing money which is funded to the investor. The association among interest rates and stock prices is well recognized. A growth in the 
interest rate determination outcome is falling stock prices due to the element that high interest rate will increase the opportunity cost of holding money, producing replacement of stocks for interest behavior securities. Interest rate is one of the significant macroeconomic variables and is directly associated to economic development. From the point of view of a borrower, interest rate is the cost of borrowing money while from an investor's point of view, interest rate is the revenue for advancing money. The interest rate is expected to be negatively associated to stock returns.

\section{EXPORTS}

Exports are the things and facilities which are created domestically and exchanged with the foreign nations, in terms of foreign currency. Export is the eldest form of economic transfer which happens on a larger scale with a few limitations on trade such as tariff and subsidies. When an exports decreases, productivity of export oriented companies also decreases. This resulted in decreased revenue streams and expectedly will have a negative impact on stock prices.

\section{MONEY SUPPLY}

Broad money supply, in accumulation of money in flow plus eyesight deposits believed by domestic non-banks also contain interval deposits as well as reserves deposits at short-notice held by domestic non-banks. Increase in money supply indications to increase in liquidness accessible for purchasing securities that eventually outcomes in upward movement of insignificant equity prices. Consequently, a positive association is estimated among money supply and stock price.

\section{UNEMPLOYMENT RATE}

The percentage of those in the labor force who do not have jobs is considered to be unemployment rate. Unemployment rate is expected to have negative impact on stock prices.

\section{B. MODEL SPECIFICATION}

The model to approximate the impact of selected macroeconomic variables on KSE-100 Index has been explained below.

Functional form of the model is as follows:

$$
\text { KSE-100 }=f(G D P, F D I, I R, X, M S, U R)
$$


Where,

KSE-100 $=$ Karachi Stock Exchange (KSE) 100 Index

GDP $=$ Gross Domestic Product

$\mathrm{FDI}=$ Foreign Direct Investment

$\mathrm{IR}=$ Interest Rate

$X=$ Export

MS = Money Supply

$\mathrm{UR}=$ Unemployment Rate

The econometric form of the model is as:

$$
K S E-100=\beta_{0}+\beta_{1} G D P+\beta_{2} F D I+\beta_{3} I R+\beta_{4} X+\beta_{5} M S+\beta_{6} U R+\varepsilon
$$

Where, $\beta_{0}$ is the intercept coefficient whereas $\beta_{1}, \beta_{2}, \beta_{3}, \beta_{4}, \beta_{5}$ and $\beta_{6}$ are slope coefficients for explanatory variables.

\section{ESTIMATION TECHNIQUE}

As our study is based on time series data so stationary properties of the variables (mean, variance and autocorrelation structure of the time series do not change over time) are also considered. Macroeconomic time series are trended and for that reason most of the time are non-stationary (having unit root problem). The main issue with the nonstationary data is that standard OLS regression technique to find the coefficients may lead to incorrect inference and this regression would be spurious regression.

\section{AUGMENTED DICKY FULLER TEST}

In order to check the stationarity of the data Augmented Dickey Fuller (ADF) test is applied on data. Results of ADF unit root test are given in table 1. We wrap up all the discussion about stationary property of the time series and conclude that all our variables are I (1). Literature suggests that if the time series are integrated at first difference level, and we should go for co-integration analysis. Hence, we apply Johansen Co-integration technique to estimate the model discussed previously. 
Table 1

\begin{tabular}{|c|c|c|c|c|c|}
\hline \multirow[b]{2}{*}{ Variable } & \multirow[b]{2}{*}{$\begin{array}{l}\text { Test for Unit } \\
\text { Root in }\end{array}$} & \multirow[b]{2}{*}{$\begin{array}{l}\text { Include in } \\
\text { Test Equation }\end{array}$} & \multicolumn{2}{|c|}{ Test-statistics } & \multirow[b]{2}{*}{ Conclusion } \\
\hline & & & $\begin{array}{c}\text { ADF } \\
\text { Test- } \\
\text { statistics }\end{array}$ & $\begin{array}{c}\text { Critical } \\
\text { Value } \\
@ 5 \% \\
\end{array}$ & \\
\hline \multirow{3}{*}{ KSE-100 } & & Intercept & 0.0605 & -2.8972 & \multirow{3}{*}{$\mathrm{I}(1)$} \\
\hline & Level & Intercept \& Trend & -2.0585 & -3.4655 & \\
\hline & $1^{\text {st }}$ Difference & Intercept & -4.9688 & -2.8979 & \\
\hline \multirow{3}{*}{ GDP } & & Intercept & -2.6766 & -2.8986 & \multirow{3}{*}{$\mathrm{I}(1)$} \\
\hline & Level & Intercept \& Trend & -3.1668 & -3.4577 & \\
\hline & $1^{\text {st }}$ Difference & Intercept & -4.3617 & -2.8991 & \\
\hline \multirow{3}{*}{ FDI } & & Intercept & -2.7048 & -2.8996 & \multirow{3}{*}{$\mathrm{I}(1)$} \\
\hline & Level & Intercept \& Trend & -2.6520 & -3.4677 & \\
\hline & $1^{\text {st }}$ Difference & Intercept & -2.9115 & -2.8991 & \\
\hline \multirow{3}{*}{ IR } & 1 ayl & Intercept & -2.8268 & -2.8986 & \multirow{3}{*}{$\mathrm{I}(1)$} \\
\hline & Level & Intercept \& Trend & -2.8401 & -3.4677 & \\
\hline & $1^{\text {st }}$ Difference & Intercept & -4.0515 & -2.8991 & \\
\hline \multirow{3}{*}{$\mathbf{x}$} & & Intercept & -1.3822 & -2.8996 & \multirow{3}{*}{$\mathrm{I}(1)$} \\
\hline & Level & Intercept \& Trend & -3.2052 & -3.4677 & \\
\hline & $1^{\text {st }}$ Difference & Intercept & -3.3448 & -2.8991 & \\
\hline \multirow{3}{*}{ MS } & & Intercept & -2.7477 & -2.8996 & \multirow{3}{*}{$\mathrm{I}(1)$} \\
\hline & Level & Intercept \& Trend & -2.3857 & -3.4677 & \\
\hline & $1^{\text {st }}$ Difference & Intercept & -3.0889 & -2.8991 & \\
\hline \multirow{3}{*}{ UR } & & Intercept & -2.3987 & -2.8986 & \multirow{3}{*}{$\mathrm{I}(1)$} \\
\hline & Level & Intercept \& Trend & -1.9515 & -3.4677 & \\
\hline & $1^{\text {st }}$ Difference & Intercept & -3.0365 & -2.8991 & \\
\hline
\end{tabular}

Source: Author's own calculations and critical values are measured at $5 \%$ confidence level.

\section{JOHANSEN CO-INTEGRATION}

Co-integration technique is used to check the long run association among variables. There are two approaches of co-integration technique. First one is Engle Granger (1987) co-integration approach and the second one is Johansen (1988) cointegration approach. Engle Granger approach is used to check long run association between only two variables while Johansen approach is used to check the long run association among more than two variables. According to the model of this study, Johansen co-integration approach is appropriate so this approach is used for this study.

In Johansen co-integration technique, basic two types of statistics, Trace statistics and maximum Eigen value are to be calculated for observing the co-integration among the variables. The trace test and maximum Eigen value test, shown in equations:

$$
J_{\text {trace }}=-T \sum_{i=r+1}^{n} \ln (1-\hat{\lambda})
$$




$$
J_{\max }=-T \sum_{i=r+1}^{n} \ln \left(1-\lambda_{r+1}\right)
$$

Here $T$ is the sample size and estimated is the $i^{\text {th }}$ largest canonical correlation. The trace test tests the null hypothesis of $r$ co-integrating vectors against the alternative hypothesis of $n$ co-integrating vectors. The maximum Eigen value test, on the other hand, tests the null hypothesis of $r$ co-integrating vectors against the alternative hypothesis of $r$ +1 co-integrating vectors.

\section{RESULTS AND DISCUSSION}

\section{A. CO-INTEGRATED VECTORS}

Following no. of co-integrated calculations has established by trace statistics and maximum Eigenvalue statistics. Conferring to possibilities specified in tables 2 and 3 , the investigation reject the null hypothesis that here is no co-integrated vector, there is at most 1 co-integrated vector, there are at most 2 co-integrated vectors and also there is at most 3 co-integrated vectors. It means that there are 4 co-integrated vectors in long run consequences. It displays high relationship among independent and dependent variables used in present study.

\section{Table 2: Unrestricted Co-integration Rank Test (Trace)}

\begin{tabular}{lcccc}
\hline $\begin{array}{c}\text { Hypothesized No. } \\
\text { of CE(s) }\end{array}$ & Eigenvalue & Trace Statistic & $\begin{array}{c}\text { 0.05 Critical } \\
\text { Value }\end{array}$ & Prob.** \\
\hline None * & 0.547780 & 207.2194 & 134.6780 & 0.0000 \\
\hline At most 1 * & 0.521236 & 145.3197 & 103.8473 & 0.0000 \\
\hline At most 2 * & 0.338920 & 87.86896 & 76.97277 & 0.0058 \\
\hline At most 3 * & 0.309814 & 55.58632 & 54.07904 & 0.0364 \\
\hline At most 4 & 0.153720 & 26.66437 & 35.19275 & 0.3061 \\
\hline At most 5 & 0.108952 & 13.64575 & 20.26184 & 0.3145 \\
\hline At most 6 & 0.057848 & 4.647928 & 9.164746 & 0.3242 \\
\hline Note: Author's own calculations. & & & &
\end{tabular}

Table 3: Unrestricted Co-integration Rank Test (Maximum Eigenvalue)

\begin{tabular}{lcccc}
\hline $\begin{array}{c}\text { Hypothesized No. } \\
\text { of CE(s) }\end{array}$ & Eigenvalue & $\begin{array}{c}\text { Max-Eigen } \\
\text { Value }\end{array}$ & $\begin{array}{c}\text { 0.05 Critical } \\
\text { Value }\end{array}$ & Prob.** \\
\hline None * & 0.547780 & 61.89969 & 47.07898 & 0.0000 \\
\hline At most 1 * & 0.521236 & 57.45071 & 40.95680 & 0.0003 \\
\hline At most 2 * & 0.338920 & 32.28264 & 34.80587 & 0.0971 \\
\hline At most 3 $*$ & 0.309814 & 28.92194 & 28.58808 & 0.0453 \\
\hline At most 4 & 0.153720 & 13.01863 & 22.29962 & 0.5549 \\
\hline At most 5 & 0.108952 & 8.997821 & 15.89210 & 0.4341 \\
\hline At most 6 & 0.057848 & 4.647928 & 9.164546 & 0.3242 \\
\hline
\end{tabular}

Note: Author's own calculations. 


\section{B. JOHANSEN CO-INTEGRATION (LONG-RUN ESTIMATES)}

Our study uses co-integration investigation to estimate the consequence of nominated variables on stock market progress. The advantage of carrying out cointegration investigation is to deliver confirmation of an established long-term equilibrium association amongst our variables. The Johansen-Julius co-integration method was used for two main causes. First, the factors are included of order one, which is the requirement of the procedure of Johansen-Julius method; and secondly, our model is a multivariate model.

Table 4

\begin{tabular}{lcccc}
\hline Variables & Coefficients & $\begin{array}{c}\text { Standard } \\
\text { Error }\end{array}$ & t-statistics & Conclusion \\
\hline GDP & 979.698 & 548.372 & 1.7865 & Insignificant \\
\hline FDI & -6487.690 & 960.995 & -6.7510 & Significant \\
\hline IR & -824.269 & 232.613 & -3.5435 & Significant \\
\hline $\mathbf{X}$ & -11274.00 & 1035.78 & -10.8845 & Significant \\
\hline MS & 2911.627 & 375.211 & -7.7599 & Significant \\
\hline UR & -3361.503 & 805.624 & -4.1725 & Significant \\
\hline Constant & 71973.84 & & & \\
\hline Note: Author's & & & &
\end{tabular}

The normalized equation for the model can be written as:

$$
\mathrm{KSEI}=\beta_{0}+\beta_{1} \mathrm{GDP}-\beta_{2} \mathrm{FDI}-\beta_{3} \mathrm{IR}-\beta_{4} \mathrm{X}+\beta_{5} \mathrm{MS}-\beta_{6} \mathrm{UR}
$$

By putting the values of coefficients in the above equation, the above equation can be written as:

$$
\begin{aligned}
& \mathrm{KSCl}=71973.84+979.698 \mathrm{GDP}-6487.690 \mathrm{FDI}-824.269 \mathrm{IR}- \\
& 11274.00 \mathrm{X}+2911.627 \mathrm{MS}-3361.503 \mathrm{UR}
\end{aligned}
$$

The long run estimations of KSE-100 index model described in a Table 4. First column is displaying the name of variables, likewise, coefficients, standard errors and tstatistics are presented in 2nd, 3rd and 4th columns. 5th column indicates whether the relationship between dependent and independent variables is significant or insignificant. According to the normalized co-integrating equation, there is a positive and insignificant association among stock prices and gross domestic product (GDP). The results reveal that the sign of the coefficient of GDP exposes that GDP is the basis of raising the stock prices of Pakistan. However the association is insignificant because $t$ statistics is less than 2 . Same affiliation has been established by Ray (2012). 
With regards to foreign direct investment, the symbol of coefficient is negative and significant is 5 percent level of significance. FDI takes place to overcome the problems of investing over capital markets, given that stockholders rights are not secure. In view of this, FDI negatively associated with the stock price of stock markets. As expected, interest rate is having reverse effect on KSE-100 index. KSE-100 index with respect to interest rate is 824.269.

A negative association among interest rates and stock prices is due to several reasons among which first is that interest rates can distress the level of business profits which in turn motivation the price that shareholders are ready to pay for the stock through expectations of higher future dividends payment. Most corporations' investment their funds equipment's and inventories through borrowings. A decrease in interest rates decreases the expenses of borrowing and thus serves as an incentive for development. This determination takes a positive outcome on future estimated returns of a firm. Secondly, as considerable volume of stocks occurs developed with borrowed money; therefore an increase in interest rates would create stock businesses extra costly. Shareholders will require a greater rate of return before participating. This behavior of investors translates in decreased demand and lead to a price reduction. These results are consistent with previous results of Nishat and Shaheen (2004), Abugri (2008), Ozbay (2009) and Saeed (2012). While the result is inconsistent with Mukherjee and Naka (1995), who established optimistic relationship among stock prices and interest rate. Similarly, Maysami et al. (2004) establish an optimistic and significant relationship among the interest rate and stock prices in situation of Singapore stock market. Ratanapakorn and Sharma (2007) in case of US stock market and Sohail and Hussain (2009) in case of Lahore stock exchange found a positive association among the three months treasury bills and Stock prices.

With regards to exports of goods and services, the indication of the constant of exports exposes that it is cause of declining in ksc 100 index of Pakistan. Ksc 100 index with respect to exports is -11274.00 . When an exports decreases, effectiveness of export oriented companies also decreases. This resulted in decreased revenue streams and decreased productivity of the companies with poor dividend payout predictions and will have a negative impact on stock prices. Same linking has been established by Hussain et al. (2012). 
Money Supply showed a positive and significant relationship with stock prices. Response of stock prices with respect to money supply is 2911.627. We can explain this relationship in this way that with improved money supply the cash liquidity improves with investors, institutions, market contributors, fund providers and fund seekers, and thus helps to decrease the markup rate and borrowing cost. Lesser borrowing cost may add to the company profitability so, influence the earnings per share of corporations positively and thus has a positive impact on stock prices. The results are consistent with the Friedman and Schwartz (1963), Bulmash and Trivoli (1991) and Maysami and Koh (2000) which indicated the positive relationship among money supply and stock prices. Similarly, AlSharkas (2004) in case of ASE, Maysami et al. (2004) in case of Singapore stock market, Ratanapakorn and Sharma (2007),Yildirtan (2007) Hasan and Nasir (2008), Sohail and Hussain (2009), Humpe and Macmillan (2009) in case of USA, Hussain et al.(2012) and Naik and Padhi (2012) found the same results. But on the other hand these results are inconsistent with the learning of Fama (1981), Geske and Roll (1983), Maghayereh (2003) which indicated the negative association among money supply and stock prices in case of Amman stock exchange. Abugri (2008) establish negative and significant association among money supply and stock prices in case of Brazil and Argentina but in case of Mexico and Chile an insignificant relationship has been found. Humpe and Macmillan (2009) established a negative association among money supply and stock prices in case of Japan.

As for as unemployment rate is concerned, it have a reverse effect on KSE-100 index. The indication of coefficient is negative which shows that the negative relationship between unemployment rate and KSE-100 index. The value of coefficient with respect to unemployment rate is -3361.501 .

\section{VECTOR ERROR CORRECTION (SHORT RUN ESTIMATES)}

Table 5 converses about the short run consequences of the model by vector error correction model. Values without brackets are short run constants, values in round brackets are presenting standard errors and square brackets are representing $t-$ statistics. The furthermost significant object in the short run outcomes is speed of adjustment term. The speed of adjustment shows that how much period would be occupied by the economy to spread at long run equilibrium. Negative indication of the speed of adjustment term demonstrations that economy will assemble towards long run equilibrium after taking 8 
percent annually adjustments in the short run nevertheless the value of coefficient is statistically insignificant.

Table 5

\begin{tabular}{lrcc}
\hline Variables & Coefficients & Standard Error & T-statistics \\
\hline Speed of Adjustment & -0.083836 & 0.04285 & -1.91175 \\
\hline D(KSC_100(-1)) & 0.007466 & 0.12830 & 0.05819 \\
\hline D(KSC_100(-2)) & 0.060046 & 0.13089 & 0.45875 \\
\hline D(GDP(-1)) & 396.5175 & 304.508 & 1.30216 \\
\hline D(GDP(-2)) & 32.93572 & 323.543 & 0.10180 \\
\hline D(FDI(-1)) & -1802.134 & 1337.49 & -1.34740 \\
\hline D(FDI(-2)) & 2845.821 & 1454.30 & 1.95683 \\
\hline D(IR(-1)) & 198.2152 & 274.466 & 0.72218 \\
\hline D(IR(-2)) & 319.2816 & 292.672 & 1.09092 \\
\hline D(X(-1)) & -991.3723 & 752.814 & -1.31689 \\
\hline D(X(-2)) & 1334.866 & 865.342 & 1.54259 \\
\hline D(MS(-1)) & 1016.485 & 284.675 & 3.57068 \\
\hline D(MS(-2)) & -490.6363 & 294.634 & -1.66424 \\
\hline D(UR(-1)) & 1751.814 & 1646.61 & 1.06389 \\
\hline D(UR(-2)) & -756.8235 & 1632.04 & -0.46373 \\
\hline Constant & 234.2920 & 111.231 & 2.10636 \\
\hline R-squared & 0.345432 & Adj. R-squared & 0.187068 \\
\hline F-statistics & 2.181261 & & \\
\hline Note: Author's own calculations. & & &
\end{tabular}

Note: Author's own calculations.

\section{CONCLUSION}

The main objective of the existing study is to discover the impact of macroeconomic determinant on the stock price variations in Pakistan using quarterly data from 1992:1 to 2012:4. In this study, KSE-100 Index was used as a replacement for the Pakistan stock prices. The macroeconomic variables are represented by the gross domestic product, foreign direct investment, interest rate, exports money supply and unemployment rate. The unit roots tests are engaged to check the stationarity of the data. All the variables used in this analysis was establish non stationary at level but stationary at first difference. The long-run associations were establish among macroeconomic variables and KSE-100 Index. We studied the long run \& short run association among share prices and macroeconomic variables using Johansen's co-integration technique \& Vector error correction model. Our results designate that foreign direct investment, interest rate, exports and unemployment rate had a significant but negative influence on stock prices. Money 
supply had a positive and significant influence on stock prices while gross domestic product had a positive but insignificant influence on stock prices.

\section{REFERENCES}

Adam, A. M., \& Tweneboah, G. (2008). Macroeconomic factors and stock market movement: evidence from Ghana. Available at SSRN 1289842.

Ali, I., Rehman, K. U., Yilmaz, A. K., Khan, M. A., \& Afzal, H. (2010). Causal relationship between macro-economic indicators and stock exchange prices in Pakistan. African Journal of Business Management, 4(3), 312-319

Asteriou, D. (2005). Applied Econometrics: A modern approach using EViews and Microfit, Palgrave Macmillan.

Bellalah, M., \& Habiba, U. (2013). Impact of Macroeconomic Factors on Stock Exchange Prices: Evidence from USA Japan and China (No. 2013-15). THEMA (THéorie Economique, Modélisation et Applications), Université de Cergy-Pontoise.

Dickey, D. A. and Fuller, W. A. (1979). Distribution of the estimators for autoregressive time series with a unit root. Journal of the American Statistical Association, 74, 427 431.

Govt. of Pakistan (2000). 50 years of Pakistan in Statistics, Federal Bureau of Statistics, Statistical Division.

Govt. of Pakistan (2011). Handbook of Statistics on Pakistan Economy 2010, State Bank of Pakistan.

Govt. of Pakistan (2012-13). Economic Survey of Pakistan, Federal Bureau of Statistics, Statistical Division.

Gujarati, D. N. and Porter, D. C. (2009). Basic Econometrics, $5^{\text {th }}$ Edition.

Hasan, A., \& Nasir, Z. M.. (2008). Macroeconomic Factors and Equity Prices: An Empirical Investigation by Using ARDL Approach. The Pakistan Development Review, 47(4), 501-513.

Johansen, S (1988). Statistical Analysis of Cointegrating Vectors. Journal of Economic Dynamics and Control, 12, 231-54.

Johansen, S. and Juselius, K. (1990). Maximum Likelihood Estimation and Inferences on Cointegration - with applications to the demand for money. Oxford Bulletin of Economics and Statistics, 52, $169-210$.

Khalid, M., Altaf, M., Bagram, M. M. M., \& Hussain, H. (2012). Long-run relationship of macroeconomic variables and stock returns: evidence from Karachi stock exchange (KSE) 100 index. The Journal of Commerce, 4(3), 45-59

Maysami, R. C., Howe, L. C., \& Hamzah, M. A. (2004). Relationship between macroeconomic variables and stock market indices: cointegration evidence from stock exchange of Singapore's all-S sector indices. Jurnal Pengurusan, 24(1), 4777. 
Menike, L. M. C. S. (2006). The effect of macroeconomic variables on stock prices in emerging Sri Lankan stock market. Sabaragamuwa university journal, 6(1), 50-67.

Nishat, M., Shaheen, R., \& Hijazi, S. T.. (2004). Macroeconomic Factors and the Pakistani Equity Market. The Pakistan Development Review, 43(4), 619-637.

Ozbay, E. (2009). The Relationship between Stock Returns and Macroeconomic Factors: Evidence for Turkey. MSc degree dissertation. University of Exeter.

Özlen, S., \& Ergun, U. (2012). Macroeconomic factors and stock returns. International Journal of Academic Research in Business and Social Sciences, 2(9), 315-343.

Pal, K., \& Mittal, R. (2011). Impact of macroeconomic indicators on Indian capital markets. The Journal of Risk Finance, 12(2), 84-97.

Pramod Kumar, N. A. I. K., \& Puja, P. (2012). The Impact of Macroeconomic Fundamentals on Stock Prices Revisited: An Evidence from Indian Data. Retrieved from https://mpra.ub.uni-muenchen.de/38980/

Rafique, A., Amara, Naseem, M. A., \& Sultana, N. (2013) Impact of Macroeconomic Variables on Stock Index (A Case of Pakistan). Elixir International Journal, 57(2013), 14099-14104

Ray, D. S. (2012). Testing granger causal relationship between macroeconomic variables and stock price behaviour: evidence from India.Advances in Applied Economics and Finance, 3(1), 470-481.

Saeed, S. (2012). Macroeconomic Factors and Sectoral Indices: A Study of Karachi Stock Exchange (Pakistan). European Journal of Business and Management, 4(17), 132-152.

Sohail, N., \& Hussain, Z. (2009). Long-run and short-run relationship between macroeconomic variables and stock prices in Pakistan: The case of Lahore Stock Exchange. Pakistan Economic and Social Review, 183-198.

World Bank, (2013). World Development Indicators. World Bank, Washington, DC.

Yogaswari, D. D., Nugroho, A. B., \& Astuti, N. C. (2012). The Effect of Macroeconomic Variables on Stock Price Volatility: Evidence from Jakarta Composite Index, Agriculture, and Basic Industry Sectors. International Proceedings of Economics Development and Research, 46(18), 96-100 